\title{
Situating the Self in Prison Research: Power, Identity, and Epistemology
}

\section{Abigail Rowe}

\begin{abstract}
Despite the central importance of ethnographic methods to sociological understandings of imprisonment, ethnographies of prison life have tended to evade ideas of "connectedness" between researcher and participant. This arguably underplays the epistemological possibilities of the unique characteristic of participant observation: the presence of the embodied, subjectively perceiving researcher in the field. Using data from English women's prisons, this article argues that attending to the (inter)subjective dimensions of ethnographic research can bring gains in sociological understanding. The analysis considers moments of disruption in field research, exploring themes of emotion, identity, and power. It focuses particularly on experiences of being positioned and misplaced by prisoners and prison staff, and of negotiating a researcher identity as a gay woman in a field in which sexuality is a pervasive theme. It is suggested that making the self visible in the text offers both substantive insights and a response to some of the dilemmas generated by even marginal participation in a complex field like a prison.
\end{abstract}

Keywords: ethnography, prison research, sexuality, coming out, women's prisons, observer effects

\section{Introduction}

From the middle of the 20th century onwards, ethnographic methods have had a central influence on sociological research in prisons (Clemmer, 1940; Giallombardo, 1966; Sykes, 1958; Ward \& Kassebaum, 1965). It is a tradition that continues to make a significant contribution to the sociological understanding of imprisonment in jurisdictions across the globe, in spite of concerns that, in an age of mass incarceration, ethnographic research has become relatively marginalized since its mid-century "golden age" (Wacquant, 2002). The contribution that participant observation has made to the understanding of imprisonment and prison institutions is clear. However, as Jewkes (2012) has observed, ethnographies of prison life have tended to avoid acknowledging the emotionality and autoethnographic dimensions of the participant observation on which they rest. Criminology, she suggests, has not been receptive to accounts of the 
emotional subtext of field research. Although a reflexive tradition is well established and vigorous in many fields of contemporary ethnographic research (see inter alia, Van Maanen, 1995; Emerson et al., 2001; Atkinson et al., 2003; Davies, 2008), in written ethnographies of prison life, the researcher often all but disappears, confined to methodological footnotes and appendices and seldom visible or acknowledged in the analysis proper. This evasion of self and emotion in written accounts of prison research defies the ineluctably embodied and - despite its realist and positivist origins - subjective character of ethnographic methods.

This article seeks to extend Jewkes' argument that admit- ting to emotion is key to understanding the research process by exploring the substantive gains in understanding that can emerge from acknowledging the (inter)subjective and embodied dimensions of fieldwork in prisons. In the analysis presented here, I take up Hammersley and Atkinson's (2007) suggestion that the participant researcher is "the research instrument par excellence" to explore the epistemological possibilities of making the self of the researcher visible (see also Anderson, 2006; Spry, 2001). The discussion draws on data and reflections from my own research in two English women's prisons and focuses on moments of disruption, emotion and "trouble" generated by my presence in the field. They revealed my different modes of participation in the social world of the prison and in turn illuminated some of its characteristics. I was aware of my presence disturbing established patterns of interaction as I slipped in and out of visibility as a stranger there, giving brief insights into otherwise unobserved relations, and the meanings and values of people and practices within the prison. I felt myself drawn uncomfortably into institutional and moral hierarchies that I wanted to resist, illustrating sharply their pervasive power. I found my own established self-meanings unsettled by the need to manage a research identity in the field. In particular, managing my position as a gay woman researching in a setting in which sexuality was a salient and contentious theme felt at times like a form of emotional participation, perhaps invisible to others, but a powerful source of understanding for me. These were embodied encounters, emotionally marked by my own or others' responses.

Taking a properly reflexive approach to participant observation is not then simply a question of making one's various positions and allegiances accountable to the reader to but- tress researcher objectivity (see Davies, 2008; Primeau, 2003; Anderson, 2006). Neither is the attentiveness to subjectivity and emotionality implied by an autoethnographic approach necessarily the solipsistic exercise that Jewkes (2012) suggests criminologists often believe. Rather, as Ruth Behar (1997) has written,

The exposure of the self who is also a spectator has to take us somewhere we couldn't otherwise get to. It has to be essential to the argument, not a decorative flourish, not exposure for its own sake. (p. 14) 
This discussion, then, seeks to do more than produce a "confessional tale" (Van Maanen, 2011 [1988]) of the experience of fieldwork. Rather, it attempts to integrate the researcher-self more fully into what Atkinson et al. (2003, p. 59) term "the ethnography proper" and examine what can be learned from reflecting on the ethnographer's presence in the prison that we could not otherwise have access to.

\section{The Study}

This article is based on fieldwork conducted in two women's prisons in the north of England over 8 months during 2007-2008 within a broader study of prisoners' coping and social support practices. The research combined participant observation, semi-structured research interviews with prisoners and uniformed staff, and a structured survey administered to prisoners. ${ }^{1}$ Following a brief pilot study, fieldwork was conducted at one "open" and one "closed" prison for women - (Her Majesty's Prisons) HMP Askham Grange and HMP New Hall. ${ }^{2}$ The pilot phase was carried out at HMP Drake Hall in Staffordshire, then a semi-open prison for sentenced women prisoners. ${ }^{3}$

HMP Askham Grange is an open prison occupying a former manor house set in modest grounds in the center of a village just outside York. At the time of the research, the prison held approximately 100 prisoners aged 18 and over in a staged resettlement regime. Prisoners (or "residents" - the preferred term of prison managers and one of a number in common usage) worked toward voluntary and paid employment or study in the local community. The prison's administrative offices, education department, and most of the accommodation were in the main house, with a small, relatively self-contained modern annex of single rooms for women in paid employment outside. The prison's separate mother-and-baby unit could hold 10 women with children aged up to 18 months, although it was under-occupied for most of the research period. Its nursery was open to children of prison staff, and from the local community.

HMP New Hall is a closed prison approximately 35 miles away from Askham Grange, also in Yorkshire. The prisons' geographical proximity meant that there was some movement of both staff and prisoners between the two, and that - in theory at least some services, such as Psychology, could be shared. ${ }^{4}$ At the time of the research, New Hall had a population of approximately 400 remand and sentenced prisoners in closed and, on one wing, semi-open conditions. A separate unit held "juvenile" prisoners, aged 15 to 18 years. The prison's diverse mixture of cellular and dormitory accommodation reflected its piecemeal development from its earlier role as a boys' detention center. Separate buildings housed a unit of small wings, larger galleried wings and a small prefabricated unit that served as the semi-open accommodation. Dedicated wings held new arrivals, women detoxing from opiates, and mothers with babies aged up to 9 
months, although for most of the research period the latter was either out-of-use or was used as an additional accommodation to ease overcrowding elsewhere. The "healthcare" wing housed prisoners with the most acute mental health problems, and a small number of women lived on the segregation unit, either for their own protection or because their behaviour could not be managed elsewhere. The women worked in light assembly or textiles workshops, attended education classes, or contributed to the running of the prison by working as cleaners, orderlies, ${ }^{5}$ or in the kitchens.

\section{Discussion}

The central participant-observation approach of ethnographic methods makes available a range of positions from complete participant to complete observer (Gold, 1958), the relative merits of which have long been described and debated by ethnographers. In penal and secure settings, the nature of the institutional environment pushes most researchers toward the "observer" end of Gold's spectrum, bringing with it well-rehearsed anxieties about the inevitable disruption the researcher's presence in the field will cause to the situated activity, the relations and practices, that she wants to observe (for surveys of these debates, see Hammersley \& Atkinson, 2007). With Hammersley and Atkinson's (2007) conception of the ethnographer as research "instrument" in mind, this article considers disruption, and the emotion that attends it, as a source of ethnographic insight, rather than necessarily a problem to be circumvented. Rhodes (2012) borrows Barthes's (1981) notion of the "punctum" - the detail in a photograph that "pricks" and "bruises" to highlight those moments in ethnographic fieldwork that break through the surface of the everyday and penetrate the consciousness of the researcher to generate new or deeper insight (see also Earle, 2013). Here, I reflect on just such emotional "punctuation points" (Rhodes, 2012); moments in my fieldwork when I was either aware of disturbing settled patterns of activity around me or experienced the process of fieldwork as unsettling to my self in ways that seemed to reveal something about the social life of the prison.

In the $\mathrm{PhD}$ thesis that presented the first iteration of this study's findings (Rowe, 2009), autoethnographic reflections were largely tidied away into a more-or-less neatly bounded methods chapter. This discussion has its origins in the process I began then of reflecting on and trying to account for my methods. For many prison researchers whose methods include participant observation of some kind, claiming the term "ethnography" raises some fraught questions about the extent to which we really can participate in or gain access to prison life, and in exactly what ways our research should or should not be regarded as ethnographic (Rhodes, 2001). Few experience what it means to sleep in a locked cell, for example, or to dispense the authority of the penal system. In this vein, Mathiesen (1965) remarks of the limitations to his study of male prisoners in preventive custody in Norway that, "I could quite obviously never become one of them" (p. 236, italics added). A number of researchers have sought qualified descriptors of their 
methods in recognition of this. Owen (1998) and Crewe (2006), for example, acknowledge the limits to outsider participation in prison settings in their respective (and I think useful) use of the terms "quasi-" and "semi-" ethnographic methods to describe their approaches. In being handed about between disciplines, definitions of ethnography have become elastic and contested. While for some ethnography remains nothing less than total immersion in the host community, for others it can encompass almost any qualitative method concerned with culture and meaning-making (Chambers, 2000; Hammersley \& Atkinson, 2007). At times, sociologists and anthropologists researching

prison life have perhaps focused on such questions of taxonomy at the expense of arguably more fundamental epistemological questions about how the field can be known, and on what basis our claims are made. Even so, it was entering into this near-ritual consideration of what kind of ethnography I thought this was, that led me to examine in detail the senses in which I thought I had been a participant in the social world of the prison.

As I've suggested, the structures of a prison make it difficult for an outsider to assume anything other than a marginal position. I was also both temperamentally most comfortable in the role of reserved participant and committed to gaining insights into the perspectives of both prisoners and staff, which seemed to demand a relatively high degree of "mobility" between groups, so limiting the depth of my identification with either (see Hammersley \& Atkinson, 2007). Despite my reserve, however, it seemed to me that there were two senses in which I couldn't avoid participating in the social world of the prison: First, in its hierarchies and second, in its pervasive identity politics. I felt continually positioned along these two axes, and was conscious of needing to manage and, at times, resist this. This sense of being drawn more deeply into the action around me than I would have chosen frequently caught me by surprise, generating feelings of discomfort and dissonance. The terms of my presence in the prison, and the modes of my participation there thus proved unstable and beyond my ability to determine. Reflecting on the experience once the uncomfortable moment had passed, however, it was clear to me that this subjective, embodied, emotional engagement was itself a powerful means through which I was able to gain a deeper understanding of the prison's relations and practices. As Alison Liebling (1999, p.164) has commented, "our emotions do not need to be reconciled with our so-called data. They constitute data." Furthermore, making emotion and the self visible in research accounts may offer a partial solution to the problems that these questions of managing identity and power present to conducting and writing prison ethnography.

\section{Troubling the Field: Identity, Hierarchy, and the "Properties" of Social Actors}

Negotiating access is an iterative process in much qualitative research. In the controlled and surveilled environment of the prison, this may be exaggerated yet further. For most 
prison researchers, accounting to participants for oneself in the prison is continual: moving around secure areas; negotiating the habitual guardedness of many prisoners and officers; navigating an institution in which, although one often encounters strangers, all can be rapidly and precisely placed (Drake \& Harvey, 2013). My own experience of fieldwork in penal establishments was shaped, I think, by my being, on the whole, a fairly inconspicuous presence in a women's prison. As a white woman below 30, I was squarely within the demographic of most of the prisoner population at the establishments in my study. Potential points of difference- my southern accent, my odd purpose there, my identification as gay - either emerged later or remained unarticulated. Dressed in civilian clothes, I could have been a member of a number of groups as neither prisoners, civilian workers, nor senior staff wore uniforms, although as a student and an observer I probably looked both less smart and less purposeful than many prison workers. Always uncomfortable with markers of status, I wore the ID badge that marked me as an "official" visitor and the keys I was issued at New Hall to allow me to move around independently, as inconspicuously as I could. The recording equipment I used for interviews was small enough to be carried unnoticed in a pocket. Although I clung to a notebook like a security blanket, at a glance, and especially in a crowd, I was probably not easy to "read," and I seemed to be difficult for staff and prisoners to place without asking. On the occasions when I became aware that there was confusion about who I was, I was generally taken for a prisoner. Or perhaps it was those that I noticed, because it was that mistake that caused most ripples.

I quickly became aware both that people were trying to place me, and that in prison, the kind of person I was had a heightened significance. It seemed to illustrate the pressures and anxieties of institutional living, and some of the imperatives of penal institutions in particular: I remember being asked early on "what I was" by a prisoner who'd thought I might be, as she said, "one of us" because I was "little" and "looked young," but who was trying to identify someone to help her see a dentist before she was released; another who wanted to make a private phone call in a wing office where I was sitting asking the officer who was taking her through into the back office where the phone was, "What about that girl?" meaning me, taking me for an inmate and clearly vigilant about the risks of discussing personal matters in front of an unknown prisoner; a uniformed officer asking me when I walked into a staff room at Askham Grange, "Are you a governor, or a prisoner?"- half joking but nonetheless clearly seeking to establish the terms on which we would engage with one another. Like both the staff and the prisoners around me, then, I was identified, positioned, and managed accordingly.

In this hierarchical and relatively low-trust environment, efforts were visibly being made to manage impressions (Goffman, 1959) by controlling the flow of personal information and selecting the appropriate mode of address for whomever one was speaking to. Conditions of need, material scarcity, and patchy service provision charged interactions 
with instrumentality as individuals sought to secure services and support. Being embedded (embodied) in these encounters gave a very immediate insight into the caution and pragmatism with which people inside prisons conduct their everyday lives; experiencing them directly meant that I had to engage with their significance to be able to respond. In contrast, my presence as an outsider sometimes seemed initially not to register at all, only to be redoubled in its impact when it slipped back into view. The ensuing confusion or emotion was the "punctuation point" that drew my attention, underscoring the recognition that a mistake had been made, and emphasizing its significance. The disruption caused by two incidents at New Hall in which I initially escaped notice as an observer, recorded afterward in my field diary were, as Rhodes (2012) would lead us to expect, fruitful to my understanding:

\section{Tuesday, October 23, 2007}

[I spent part of the afternoon observing an IT lesson.] There was a boisterous girl in the corner, Kirsty ${ }^{6}$... I sat and chatted to a woman I recognised from G Wing as she did her work...

[The lesson wound down] well before the end of the session. A young female officer came in to search the women before they left. Sitting apparently aimlessly at one of the computers, she took me for an inmate ("Come on, Miss!,", chivvyingly). My thoughts were elsewhere and it took me a moment to work out what she meant ("Oh! Oh no, I'm not a prisoner ... "). When she left, Kirsty commented [of the officer], with some enjoyment, "She went well red!"

Several elements of this incident are noteworthy: what looked to me like the officer's embarrassment at making an error in front of inmates; her apparent sense that she had insulted me; the prisoners' pleasure at her discomfort, all spoke to the often-strained quality of relations between staff and prisoners at this establishment. Where the categorization of bodies is a bureaucratic and moral imperative, a failure of this kind troubles the settled order that the prison regime seeks to achieve. Here, the officer's efforts to "make" an authoritative role for herself (Goffman, 1959; Rowe, 2009) faltered, itself a small victory for the prisoner. That this mattered was marked by the emotion it generated in both.

Confusion of this kind continued, to a degree, even as I became an established presence at New Hall:

\section{Monday, January 7, 2008}

[I was standing on the upstairs landing on E wing at lunchtime, talking to Helen and Jan] ... Miss Lewis approached, locking in. Jan commented that it was time for them to go back in, and something about my having been caught "Speaking to the enemy." As I 
headed back downstairs, Miss Caldwell, seeing me out of the corner of her eye, began to say, "Where are you going?!," then saw it was me and apologised, embarrassed. ${ }^{8}$

The moments in which I was absorbed into the action of the prison - at least in the awareness of some of those around me - were no doubt fleeting. As I have already suggested, they felt like slippages between invisibility and visibility as an outsider to the institution, and where they were marked like this by embarrassment or confusion, they were revealing of social norms. They exposed - if only momentarily - the tone of the unobserved officer addressing an inmate. The intensity of the officers' discomfort in these moments seemed to reveal a consciousness of the gap between the way in which I had been addressed as an imagined prisoner, and the more respectful tone usually afforded to a visitor. Perhaps this might be called something like quasi-participation: being subsumed briefly by the action completely and then slipping back into visibility as an observer. This was one of the ways in which my participant position seemed unstable, as if shifting from total participant to total observer, at least in the awareness of others. Owen (1998) similarly notes how being mistaken by staff for a prisoner during her fieldwork in a Californian women's prison gave emotional insights into the experience of confinement. In my own research, the degree of discomfort caused by such miscategorizations varied between establishments. In the more relaxed atmosphere of Askham Grange, endearments such "love" and "duck" were usual terms of address both within and between the staff and prisoner groups. There was less often a significant difference in the tone in which staff and prisoners were addressed, so mistakes were less marked, and less charged with obvious meaning.

In these moments, slight disturbances caused by my presence felt instructive. Goffman (1971) remarks that the purpose of ethnography is to "derive the properties of individuals from observable situated activity." On several occasions, the confusion I generated seemed to expose the "properties" of particular social actors and the significance of the practices I observed more clearly than if everything had continued smoothly and uninterrupted. The fieldwork incident that illustrated this most vividly to me took place during an early observation in the busy Reception at New Hall:

\section{Tuesday, November 13, 2007}

[One of the Reception officers] Jo Moore ... seemed to adopt me - I don't know why. Having begun the day as "Abigail," by the end of the shift I was "Little Abi." It was Jo who made sure I was offered drinks, and - because I ended up staying so late - that I got a meal. She progressively put me to work - initially just asking me to pass her this or that, and then ultimately helping her fill in prop [property] cards. 
Reception is made up of three sections: an entrance area with some holding rooms and a counter; a middle room with a counter and the SO's ${ }^{9}$ office off it; a back area where the shower, kitchen and an "inner" holding area are. I was standing in front of the counter in this middle room when Jo asked if I wanted a drink and asked Margaret the orderly if she'd "Get Miss a black coffee." She duly brought me a coffee, and a little while later, standing in the doorway between the two outer rooms while Jo and a couple of other officers went through some property, I lifted the cup to take my first sip. Jo was facing me, caught sight my light blue plastic cup and looked absolutely aghast: "Where d'you get that?!" I (nonplussed) said that Margaret had brought it to me. Jo - seemingly quite horrified - said that it was a prisoners' cup: "Don't drink from it." I said I really didn't mind, but she shook her head, wrinkling her nose, and took it from me back out to the kitchen. A minute or two later, Margaret brought me a replacement coffee, laughing in embarrassed apology that she'd thought I was a prisoner. I told her that it was fine - I didn't mind what I drank from - there'd been no need to change the cup, and it had been perfectly natural to take me for a prisoner, standing where I had been . . .

I felt drawn into the prison's power relations in a number of ways here. Participating in the officer's work seemed to add a note of ambiguity to my position; and, as always, I forgot in my gratitude at being offered a drink by an officer that accepting it would probably mean that a prisoner would immediately be instructed to bring it. I never got used to, or felt comfortable with, this. I experienced ongoing, irresolvable tensions between the imperatives to respond positively to the officer's social overtures, meeting the physical demands of my own thirst, hunger, and caffeine withdrawal during a long day at the prison, and trying to hold myself apart from the institutional power by which prisoners were processed and subordinated.

This internal discomfort was all displaced, however, by the crisis of confusion and panic about the cup I had been given. The fallout from this simple misunderstanding drew my attention to the different crockery used by staff and prisoners, and its previously unconsidered significance. I'd seen that the officers used their own ceramic mugs, which were kept on a separate shelf in the kitchen area, but with- out this incident would probably not have thought much more about it than I would about the cups in a school staff room, or that office workers choose to bring in from home. Here, I was taken aback at the visceral disgust manifested in the immediacy and strength of the officer's reaction, the ideas of stigma and contamination that it revealed, and the suspension of the norms of politeness that would in another setting have made it unacceptable to express revulsion or insist that the mistake be corrected. It seemed to me that the cluster of ideas and beliefs exposed in this moment were not ideas that the officer would have (could have?) articulated in a research interview. In any case, I wouldn't have known how to formulate a question that "tapped" it, and even if these associations were conscious ones, I suspect she would have been reluctant to express them. These were not insights that would have 
been available by any means other than being there as an embodied social presence, a person ${ }^{10}$ with particular "properties" of my own, albeit uncertain ones. The disruption that accompanied the process of ascribing "appropriate" meanings to me was instructive. Again, the emotion generated when mistakes were made - disgust, embarrassment - gave an uncensored commentary on their significance that was unlikely to have been accessible in any other way.

In a smoothly-realized routine encounter, the tacit rules organizing a setting's relations and practices remain submerged and may go unnoticed by the outsider-observer, because there's little to direct attention to things that have an unanticipated meaning; before the officer reacted as she did, it hadn't occurred to me that the mug I'd been given had symbolic significance. Lacking an "indigenous role" and ignorant of social norms, the outsider-observer is not easily placed and may disrupt established relations in ways that "trouble" the smooth-running of social transactions (notwithstanding, of course, that the actors inside prisons may not be invested in things running smoothly; many prisoners actively resist in all kinds of ways, and officers themselves adopt variant roles [BenDavid \& Silfen, 1992; Farkas, 2000; Tait, 2011]). This seems to me to be one of the ways in which the practice of ethnography can "make the familiar strange," both to the observer and, perhaps, to participants in the field, itself "punctuating" the situated activity under observation and making it legible.

The prison officer in this incident had - in her attempts to be welcoming by occupying me - drawn me slightly beyond my preferred position of detachment by involving me in her work. However, my corner of Reception felt sufficiently "backstage" that any compromise to my appearance of independence felt tolerable, and the trade-off against my desire to acknowledge the officer's kind intent, and avoid alienating her as a potential interview participant felt worth it. It did feel odd to contribute to official prison documents, however, and I was struck - as so often in the course of my fieldwork - by how rapidly decisions about how to present and conduct myself had to be made, and how uncertain the consequences of those decisions were. I often wanted time I didn't have to consider how I felt and what I should do, and the case for reserve felt impossible to make "in the swim" of the action to hard-pressed prison staff who wanted an extra pair of hands to carry out what to them were straightforward, everyday tasks, but which to me - with my unease at practices of power and punishment and desire for separateness - felt fraught with confusion and compromise.

During my fieldwork, there were a number of other occasions on which members of prison staff - seeing me, I think, as being there in some kind of "professional" capacity (although who knew quite what, or why?) - also asked me help out with little tasks. Although undoubtedly due in part to the pressure staff were under (women's prisons are relatively lightly staffed, and New Hall at this time was experiencing high levels of both 
staff absence and prisoner receptions), some of these instances may have arisen from attempts to manage the discomfort of feeling observed, or even to "colonize" and domesticate a potentially threatening stranger. Some of these experiences felt more deeply compromising to my efforts to hold onto and make visible my distance from the institution. One such incident took place during a day's observation on the semi-open wing at New Hall:

\section{Friday, November 2, 2007}

The day's post arrived just before the women returned from work for dinner. The post was sorted into ordinary post, which had been opened already, and legal post, which was separate so the women could open it themselves in front of staff. As they got in, the women came to the office to ask for their post. They came in throughout their lunch hour, and while the officer oversaw the lunch queue she asked me if I'd mind handing out letters if anyone asked (this arose because the servery is just outside the office door, and space is so short that there wasn't really anywhere other than the office for me to be while everyone queued for food because it was a bit of a crush). Although I've come across and chatted to a number of the women on the wing, I've certainly not met anything like a critical mass of them to make me feel as though I'm generally known by prisoners, or that it's clear that I don't work for the prison, so this was a little uncomfortable. One of the women I'd seen coming through Reception the other day came and asked for a letter from the pile of unopened post, in addition to an ordinary letter. I told her that I didn't think I was allowed to give it to her because it needed to be opened in front of an officer (and that I was not one). She kept insisting (slightly aggressively) that the letter was there and yes she could have it. It felt as though it took a lot to persuade her that I couldn't give her the letter, and she kept agitating for it. I felt incredibly uncomfortable, and very annoyed that I'd been put in this ambiguous position ...

This experience left me reeling. It was the stuff of a very ordinary, low-level confrontation between a prisoner and a member of staff. Exercising this kind of discretionary power in face-to-face encounters is continual in prison officer work (Liebling, 2000; Liebling \& Price, 2001; Mathiesen, 1965; Willet, 1983) and as soon as I was placed in this role - even without any of the authority that made it meaningful - I felt myself positioned within this potentially conflictual dynamic. The reasonableness of my explanation that I had no authority didn't matter to the woman who wanted her letter. It was of no importance to her whether or not I had any investment in the rules that said she couldn't have it, any more than it had occurred to the officer that this task might make me uncomfortable, or be incompatible with my own purpose there.

Here again, were tensions between the need - common to all ethnographers - to maintain civility to my "hosts" in the field in recognition of my imposition on them and in return for the access I was granted, and to remain visibly distinct from it. But who were my 
hosts? The officer here had allowed me to spend the morning sitting in the wing office. She did not have to and could have asked me to leave. My presence was at least as great an imposition on prisoners, however, who could not choose to refuse me admittance, except to their own rooms. The discomfort and anxiety I felt on this occasion pointed to the singular transactions of power that structured my encounters with the officer and the prisoner. In this moment, the dilemmas arising from my conflicted position felt intractable. It may be, however, that writing these dissonances back into my analysis of the incident not only puts the self to epistemological use by making the emotional responses that so clearly delineated the power transactions here but also offers a way of managing some of that conflict. Denzin describes what he terms "messy" ethnographic texts (Denzin, 1997. See also Denzin \& Lincoln, 2000; Lincoln \& Denzin, 2005) as reflexive, multi-voiced, exposing the writer and refusing the authority promised by "the myth of silent authorship" (Charmaz \& Mitchell, 1996). Making the self visible as situated and subjective makes a different kind of position available from that of the univocal realist ethnography still typical in prison research. This circumvents the need to adopt a stable set of allegiances, and so perhaps offers a way of mitigating my sense that I must either be complicit in the disposal of forms of power that I could not fully endorse or was rejecting the hospitality of my hosts (see also Liebling, 2001).

As I have already suggested, and as Goffman (1971) implies it should, thinking autoethnographically about my own encounters in the field reveals some of my own "properties" in that context. Because my outsider status and apparent rolelessness made me an obscure presence for many, there were times when others seemed to "fill in the blanks" with meanings that perhaps shed more light on the social world of the prison than they did on me. I felt myself positioned variously as professional, naïve outsider, eccentric left-winger. The glimpses I caught of the ways in which others appeared to imagine me were often seemingly generated by others with little prompting from me, and clear reflections of the preoccupations, assumptions, and self- conceptions of actors in the field. As in previous examples, the position I occupied was not stable, and was as much ascribed to me as chosen by me.

One example of being positioned by a basic-grade prison officer as "the professional" who could adjudicate on appropriate practice was rich with layered meanings about punishment, penal practice, and status of prison officers. I was spending the day on the largest wing in the prison, which held the long-term prisoners. During a discussion about the types of prisoner held on the wing, the conversation turned to the Governing Governor's recent decision to grant permission to two women in a relationship to share a cell, which overturned what had until then been official policy. There were several of us in the office, but one long-serving but basic-grade officer steered the conversation:

Wednesday, November 7, 2007 
... She clearly disapproved. I asked if couples sharing cells presented specific managerial/operational problems (such as - though I didn't suggest anything to hercoping with the fall- out of intense relationships: frequent moves when relationships began/broke down; staff having to distinguish between serious/non-serious and healthy/unhealthy relationships ... ). She said, "Well why should we?! It's like giving them their own self- contained flat!" Her reaction was clearly completely visceral (mildly interesting in light of the fact that I think she might be gay, in which case I suppose this instinct would be about punishment ... ). "You're the professional—what do you think?" Were there murmurs here from her colleagues to tone down what they read as antagonistic? I think there was certainly an edge of that, at which she protested, "No! I'm interested!" I think my response was that in this, she was the professional, not me ...

I had perhaps irritated the officer by asking for an explanation of what was probably to her self-evident, but there was an audible sharpness to the word "professional," amplified by what I thought was the demurring of the others present and my own obvious attempt to deflect it. It was not, after all, an identity that I had sought to claim for myself. Her use of the term seemed loaded with the sense of injury shared by many of her colleagues at that time: overruled and subordinated to prisoners' interests by new-broomish managers; their experience and procedural knowledge unvalued and irrelevant; hurried into change they did not necessarily approve of (see Crawley, 2004; Liebling \& Price, 2001). It was challenging and defensive, tinged with suspicion, even scorn, of the views of those who like me, like the Governor - viewed and understood the prison from the comfortable distance of our ivory towers rather than her own more grounded vantage point on the landings.

My presence as an observer, then, seemed to "trouble" the field in a number of enlightening ways. The ways in which I felt my presence disturb the setting were often deeply revealing of attitudes, practices, and social relations. They underscored the significance of the embodied character of ethnographic research, its "relational, emotional, personal" nature (Atkinson et al., 2003, p. 56). As Jewkes (2012), Liebling (1999), and others indicate, however, and as suggested at the outset of this discussion, the relationship between field and researcher is a recursive one. I found as I attempted to navigate the structures and social relations of the prison and negotiate a tenable position for myself, that there was an insistence to the social dynamics in each of the prisons that was difficult to resist, a persistent pull to position me along those indices of identity and hierarchy on which the compelling logic of the prison demands that everyone be placed. As so often in fieldwork, "making" and holding my chosen role as a reserved participant was a continuing negotiation, and often felt deeply compromised by the nature of the setting in ways that unsettled me.

\section{Troubling Me: Sexual Identity, Silence, and the Contours of Power}


Ethnographic fieldwork is not simply a personal process, but a dynamic one; "the actual lived experience of fieldwork confronts, disrupts, and troubles the self" (Atkinson et al., 2003, p. 54). Atkinson et al. (2003) primarily consider how the experience of fieldwork impacts on the ethnographer's experience and understanding of self-identity. The confrontation, disruption, and troubling of the self that they describe, however, also offers a source of insight into understanding the experiences and practices of actors in the field. In this way too, then, the self is the ethnographic "research instrument" (Hammersley \& Atkinson, 2007).

Themes of identity and power run together hand-in- hand - always, but especially in prisons, where no-one ever just happens to be, and in which who one is of profound material and moral significance. Many ethnographers describe navigating dilemmas of self-presentation in the field as a process of finding a position that balances their own comfort and that of the group under observation. The researcher-self must be made in order to achieve a position as an "acceptable marginal member" (Hammersley \& Atkinson, 2007). In prisons, this means managing the impressions of both staff and prisoners (Drake \& Harvey, 2013; Liebling, 2001). I was most conscious of doing this work in micro-level improvisations in the kinds of encounters I have discussed above: attempts to distance myself from the regime in the eyes of prisoners without seeming to cast negative judgment on the business of staff; seeking a line between appearing trusting and credulous; trying to ensure that I was as responsive and reliable I could be, but without sacrificing boundaries. I was certainly conscious of making mistakes. It was precisely when things went wrong, however, that I became conscious of these as powerladen transactions. Changes to arrangements for interviews with prisoners, for example, were hampered by the obstacles to direct communication and vulnerable to being overwritten by institutionally-shaded scripts of disingenuousness and disrespect. Likewise, my anxieties at being aligned with the symbols of regime power: cups and keys and refreshments offered by staff but brought by prisoners. Attempts to "make" my researcher identity and to position and re-position myself within complex encounters in the field often felt reactive and largely instinctive.

Some decisions about my self-presentation, however, were perhaps more strategic: how to present the project to make it understandable and seem worthwhile (with inevi- table changes of emphasis in versioning this for different staff groups, managers, and prisoners); how to dress to con- vey an impression of being credible and "together," but approachable and - preferably - distinct from prison staff; what personal information I would disclose or withhold. As a (usually) "out" gay woman researching in women's prisons, questions and anxieties about self-presentation coalesced around ideas of (not) coming out. This was a uniquely persistent dilemma in the research, partly, perhaps because, transposed to the prison, my settled patterns of identity management were unsettled somewhat. The anxiety it generated was indeed a "confrontation of the self," to 
revisit Atkinson et al.'s phrase. It dogged me throughout my fieldwork. Although this anxiety felt in some ways like a burden and an obstacle, I came to understand it as itself a kind of emotional participation in prison life and capable of illuminating something of what it is like to manage an identity in a closed and often hostile institution.

In another research project, my sexual orientation might have felt completely irrelevant. In women's prisons, however, sexuality is significant. Since the early 20th century and up to the present day, sexual and romantic relation- ships between women prisoners have been a preoccupying theme for researchers (inter alia, Einat \& Chen, 2012; Freedman, 1996; Giallombardo, 1966; Howe, 1994; Otis, 1913; Severance, 2008; Ward \& Kassebaum, 1965), and gay and bisexual-identified women represent a significant minority of prison officers. The lesbian, gay, bisexual, and transgender (LGBT) staff group is active and visible. During my preliminary visit to Askham Grange, for example, I noted a large, framed rainbow flag carrying its logo displayed in one of the prison's central corridors. I thus began my fieldwork knowing that same-sex sexuality was likely to be in some way significant in the research sites, and participants confirmed early on in the research that in many English women's prisons it is not uncommon for even straightidentified women to enter into erotic and romantic relationships with one another. Added to my desire for personal reserve, the significance of sexuality in this field left me uncertain as to whether or not coming out myself would be either expedient or comfortable.

Although "coming out" is commonly treated as a one-off rite-of-passage event in queer lives (see Orne, 2011), it is of course a recurrent experience, rehearsed and revisited as one encounters new people and places. Orne describes what he terms "strategic outness" as a "continual contextual management of sexual identity". Day-to-day, "outness" - for me - is almost always preferable. Conducting fieldwork, deciding whether to disclose this concealable characteristic became folded into and complicated by those other questions about managing an identity in the prison. Not generally being "read" as gay, coming out for me usually entails some kind of active disclosure. When others assume heterosexuality, not making that act of disclosure can quickly come to feel like an act of concealment.

An observation very early in my fieldwork at Askham Grange made me feel I needed to understand more about the significance of sexuality there before deciding to come out. I was spending a slow Friday afternoon in the prison's Reception and the two officers posted there - BethClarke and Miss Harvey in the fieldnote below - had called over the tannoy to an officer working elsewhere in the prison, their friend Em, to come and join them for a cup of tea. Two others, Miss Campbell, who was "young-in-service" but herself somewhere in her 40s, and a woman I didn't know had also dropped in for a chat on their way past. Also there was the Reception Orderly, who was a similar age and 
whose relationship with the officers seemed relaxed, but distinctly subordinate:

\section{Friday, May 18, 2007}

Beth Clarke, Miss Harvey and Em are all gay ... and this definitely affected the atmosphere in the room, which seemed to a degree sexualized - when discussing Em's recent weight loss, Beth and Miss Harvey agreed she'd lost enough, Beth saying, "You've gone too far for me now - I've gone off you" and there was quite a lot of mockflirting; Beth told Em and Miss Harvey about a young blonde woman in an officer's shirt but no epaulettes she'd noticed in the car park slightly earlier and wondered who she was, which became a conversation about who the "fit blonde" was. I suppose the majority of the well-established officers in the room were gay, i.e. a majority of the high-status people in the room, which seemed to facilitate a kind of homonormativity in the conversation, so that the couple of straight officers, notably Miss Campbell, were kind of falling in with that norm, and laughing along with the conversation; it struck me as being the obverse of the more common situation of being the only gay woman in an office laughing along with the girls/trying to keep your head down when the conversation turns to firemen and hoping no-one addresses you directly on the subject ...

I was fascinated by this scene and the dynamics between the women in the room that it suggested. The confidence shown by Beth, Em, and Miss Harvey not just in referring to their shared lesbian identities in a mixed group of col- leagues, but doing so in undoubtedly sexual terms was striking. Furthermore, their conversation held the floor, so that it was the others of us in the room who were positioned as marginal. As I noted in my field diary, I felt as though I recognized in Miss Campbell's demeanour an inverted version of a social awkwardness, an embarrassed marginality, and desire to avoid attention, that I was familiar with from the experience of being among groups of straight women talking about men. It confirmed absolutely her heterosexuality, and struck me as something I'd not seen in quite this way in any other workplace I'd known. It resonated with my expectation that sexuality might prove a salient - and perhaps sensitive - theme, and increased my uncertainty about what I would disclose.

The conversation raised questions about the prison that made me cautious about outing myself. If the small, but mixed, staff of uniformed officers contained a visible clique of assertive - and assertively gay - women, how might that affect relationships? Was there any backlash from their male and heterosexual female colleagues? What did prisoners think? The experience I brought with me to the field of managing my own sexual identity and outness sensitized me to the scene I had witnessed, the possible meanings it might hold, the probable emotions and relations in which it was rooted. These were things I knew intimately and felt I recognized immediately. The officers' own openness about expressing their sexual identities did not, of course, indicate that the meanings they carried within the institution were positive, or even neutral: might not a close, confident 
minority, coloured in the eyes of others by wider social stigma, attract some more ambivalent responses from colleagues and prisoners? In an organizational culture characterized by at least surface friendliness (and a fair measure of backstage bitching) would I be able to explore any such ambivalences if I were out myself? The officers' excitable response to the appearance of the unknown woman made me worry that disclosure might - with the ready bonding that often arises between members of all kinds of minority groups - lead to a level of assimilation by this group of women (if, of course, this was a group in a meaningful sense). As Moore and Jenkins (2012) point out, disclosure is irreversible, and I worried that an association with a particular group (and a potentially divisive one?) might threaten my "mobility" within the field. Prisons are also characterized by high levels of gossip, and most agreed that this was especially true at Askham (as indeed this scene suggested), where staff were less guarded than in closed conditions, and there were few restrictions on prisoners' ability to socialize with one another. It seemed unlikely, then, that I would be able to differentiate the way I presented myself very effectively between individuals. I probably needed to regard coming out to one person as a public declaration, and should avoid disclosing to anyone what I was not willing to be universally known. This element of self-presentation, only half-considered before the fieldwork began, touched some deep and even painful places. I began to feel a little of the process of identity management that membership of a total institution must entail. I'm not sure I would have noticed it had I not had to do it in a way that felt so deeply exposing and personally risky.

Despite the familiarity of these anxieties, however, the contours of this dilemma were unique in my experience, running along lines that were specific to the prison setting and giving insights into its topography. As I moved from open to closed prison conditions, I became aware of the sense of sexual vulnerability shared by many prisoners, who commented on the experience of seeing a male officer's eyes at the cell door when they were undressing, and the inconsistency whereby a man could not strip-search them, but a lesbian could. This became connected with my consciousness of eroticized cultural fantasies of women's prisons and the stereotype of the voyeuristic, predatory dyke (Ciasullo, 2008; Freedman, 1996; Herman, 2003; Rowe, 2012), with which I had a horror of being associated in the eyes of participants who knew better than I did that prisons are about pain. The details of my uncertainty about coming out, then, were partly responses to the institution, conditioned by my consciousness of the steeply asymmetrical power relations of the prison, and my desire to remain outside them as far as I could. Also unsettling was the incongruity of finding myself suddenly reticent about my sexual identity in a set- ting where - of all places - it shouldn't raise an eyebrow (should it?), where I saw obviously gay women every day, and where (at New Hall especially) it was not uncommon to hear even straight-identified women chatting openly about their current and ex-girlfriends, and where gossip about flirtations and break-ups between inmates was 
frequently shared by staff and prisoners alike.

My reflections brought insights into the pressure that the prison exerted on the process of identity management that I think all experience (see also Greer, 2002). My position as an outsider was also crucially significant to the complex social and institutional power relations associated with these issues that I began to perceive. Both my understanding of the profound disempowerment that made prisoners a potential object of a voyeuristic gaze, and my awareness of the stigmatized societal meanings that still attach to lesbianism were in play in my anxiety. I was at once, then, worried by my marginality, vulnerability, and my relative power. My settled practices and self-meanings were disturbed by the context of the prison, and the research, but this disturbance was a means through which I could understand it.

The position I came to occupy never felt like an easy or stable one, neither politically nor personally satisfactory. The decision to not/come out became a rolling deferment until time ran out. By not disclosing, I gained some data I might otherwise not have done: confidences from straight- identified women about their shock and unease when they first came across lesbian activity among prison inmates; discussions about how the prison should manage prisoners' intimate relationships. Other lines of enquiry were some- what circumscribed, however. Unwilling to ask questions that I wasn't sure I would answer myself, I did not instigate personal discussions about prisoners' experiences of sex and relationships in prison, although they were volunteered by some and appeared as footnotes in the narratives of others. I would not lie, but I nevertheless remember the rush of panic I felt when, during an evening event in the Chapel at New Hall, two women playfully involving me in their bored banter seemed suddenly to stray into my buffer zone of silence:

\section{Wednesday, October 31, 2007}

Frances and Stella were messing about and kind of drew me in. Stella said to me (something to the effect) that, "Frances fancies you ... " I (a bit embarrassed) made some remark about knowing Frances to be a respectable married woman and a grandmother, so I knew that she didn't. Frances (who must be in her forties), a little distance away, was protesting to Stella (also to me, indirectly) that she didn't but that Stella did and she was a lesbian. Stella: "I'm not! I'm not! I gotta man in prison!" They'd been having a bit of a tussle a couple of feet away and directing some of their interaction to me. Now Stella came back up to me and said directly to me, with animation and standing quite close, "There is a thing called gay, and a thing called jail bent - and I'm jail bent." Then a brief pause (like beginning a new paragraph), and then, "Are you young?" I misheard her, thinking she'd said, "Are you one?" (like, a lesbian). I felt flooded by embarrassment ... It took me a moment or two of (I'm sure) flushed stuttering to work out what she had said, and find I didn't quite know how to answer that, either: "Er, don't know. I'm 
twenty-eight ... ?" The verdict was positive - she nodded approvingly that anything in the twenties was okay...

Before Stella asked her misheard question, my interest had been absorbed by her complex attitudes and identifications: Comfortably calling herself "jail bent" (and flirting a little while earlier with apparent intent with the girl sitting in the row behind her), but lesbianism itself still eliciting giggles and vehement denials. In that moment I was caught off balance, again wishing I had more time to steer a more careful course. The wave of relief I felt at realizing I did not have to answer a question that would either out me decisively or prompt a denial that was dis- sonant with my deeper identifications and commitments, was accompanied by some amusement at the nakedly Freudian nature of my mishearing, which highlighted to me the evasions I had been relying on. My strong and physical reaction to this incident demonstrated that more was at stake emotionally than I had been aware of. It was the punctuation point that illuminated this tangle of meanings around prison sexualities.

The kind of collision between inside and outside behaviours and identities that I experienced in attempting to negotiate a "prison persona" was described time and again in my interviews with prisoners; painful disjunctures and tensions between selfconceptions, expedient self-presentation, and the perceptions and postionings of others. In experiencing my self as disrupted, just as when my presence seemed to cause disruption, my embodied and emotional involvement in the field allowed me to come to particular understandings of the social world of the prison that might not otherwise have been available to me. It is this opening up of otherwise unavailable meanings that Behar (1996) suggests must be achieved by making the ethnographic self visible if it is to earn its place in the text. It both illuminated specific norms and practices and offered insights into the emotional tenor of prison life: the challenge of identity management in a closed, low-trust, inward-facing institution; the pressure of managing dissonances within and between "imported" and "situational" selves. For me, this affective involvement in these ubiquitous negotiations felt like an additional, if unspoken, form of participation in prison life, which carried an epistemic impetus of its own.

\section{Conclusion}

all ethnography relies on the perception of the researcher, who comes to know the field bodily, intuitively, and emotionally, as well as intellectually and through the accounts of others. Through attentiveness to all these ways of knowing, we can engage more fully with the social worlds we study, and come to insights that might not otherwise be available. In its minimal form, reflexivity in the realist ethnographic tradition serves as a way to manage and neutralize the "problem" of researcher subjectivity. As Davies (2008) reminds us, however, it is that very subjective, intersubjective, presence of the researcher 
that generates the data on which all ethnographic analysis rests, whether this is acknowledged or not. This discussion has argued that the disturbances that arise from the ways in which the researcher and the field act on one another can give rise to substantive insights. Atkinson et al. (2003) suggest that - while the researcher-self has always been at the heart of ethnographic methods - the significant innovation of post-realist ethnography is to make that self visible in the text. While this visibility has often remained marginalized in confessional "tales of the field," more recent studies have sought to integrate the two, making the self an analytic tool. Following this, I have suggested that admitting to our embodied and subjective presence in the field becomes both a source of substantive understanding and a solution to the discomfort and compromises that even marginal participation in a complex field like a prison inevitably entails. In renouncing the fallacious and epistemologically untenable position of "silent authorship" (Charmaz $\&$ Mitchell, 1996) and showing the self, it becomes possible for the researcher to occupy a more dynamic, conflicted role because it ceases to be necessary to hold a single position and set of allegiances.

Considering the multiple ways in which I thought I had been a participant in the world of the prison led me to reflect on how difficult I had found it to remain outside the prison's hierarchical structures and its persistent demands around identity: what are you? who are you? Power flowed in both immediate and diffuse ways around and through those negotiations. These were questions of instrumental significance - who could do what for or to whom; a multi-layered moral ordering of "spoiled identities" and "normals" (Goffman, 1963); collisions and strain between outside and inside selves and statuses. The experience of being drawn into and having to navigate those relations - both internally and in encounters with others - became a way of accessing, understanding, and organizing glimpses into the prison world, its powerful logics, practices, and emotional pressures.

There are of course clear dangers in making the researcher-self visible in social research. As Davies (2008, p. 10) warns, excessive reflexivity is as unhelpful as the extremes of realist and positivist ethnography, risking "sterile and precious self-consciousness" or an absolute blurring of the distinction between subject and object. Furthermore, there are sound reasons for safeguarding a sense of the "real" in ethnography (Anderson, 2006; Davies, 2008; Van Maanen, 2011 [1988]), which must be especially true in a politically charged field like criminal justice. Nevertheless, all ethnography relies on the perception of the researcher, who comes to know the field bodily, intuitively, and emotionally, as well as intellectually and through the accounts of others. Through attentiveness to all these ways of knowing, we can engage more fully with the social worlds we study, and come to insights that might not otherwise be available.

\section{Funding}


This research was funded by a grant from the UK's Economic and Social Research Council (ESRC), Ref. PTA-030-2005-00058.

\section{Notes}

1. For a fuller account of the research sites and methods, see Rowe (2009).

2. Because of the size of the women's penal estate in England and Wales, it is impossible to anonymize the prisons effec- tively without removing almost all descriptive detail.

3. Because of their relatively small number, women's prisons are categorized as simply "open" or "closed," rather than by the more differentiated levels of security used in the men's prison estate. An open prison equates to the lowest category of security in the male estate. There are no internal locks, except on staff offices, and the site is not secure. At Askham Grange, the building was locked only at night. "Semi-open" conditions allow prisoners to move freely within a prison or a wing within a secure perimeter. Since the research, Drake Hall has been "re-roled" as a men's prison, and this classifi- cation no longer exists for any whole prison, although, as at New Hall, otherwise closed prisons may include some semi- open accommodation.

4. The two prisons were administered separately at the time of the research, but have since been brought together under the management of a single Governing Governor.

5. "Trusted" prisoners employed to support officers by carrying out work essential to the running of the prison.

6. All names are pseudonyms. The same pseudonyms are used in all written accounts of the research.

7. "Miss" was the typical title for both female staff and prison- ers. A member of staff would generally address a prisoner s/ he didn't know as "Miss" but call a woman s/he knew by her preferred forename.

8. At New Hall in particular, which had a reputation as slightly old-fashioned, modes of address operated rather like those in a school. Staff usually addressed each other in front of prisoners (and often even in "backstage" areas) as Miss or Mr So-and-So, so that this is how I often thought of officers. My interchange- able use of forenames and titles for staff reflects this. Except on the couple of occasions when I was telephoned by the Gate at New Hall to admonish me for forgetting to inform them when I was onsite out of hours, when I was "Miss Rowe", I was always called "Abi" or "Abigail."

9. Senior Officer: middle-ranking uniformed officers.

10. I follow Cahill's (1998, p. 135) usage of the term "individual" to denote an "organic bodily 
being," "person" to refer to what Harré (in Cahill) calls the "socially defined, publicly embodied being," and "self" to mean the being's "reflexive aware- ness of personal agency and identity."

\section{References}

Anderson, L. (2006). Analytic Autoethnography. Journal of Contemporary Ethnography, 35, 373-395.

Atkinson, P., Coffey, A., \& Delamont, S. (2003). Key themes in qualitative research:

Continuities and change. Walnut Creek, CA: AltaMira.

Barthes, R. (1981). Camera Lucida: Reflections on photography. New York, NY: Hill \& Wang.

Behar, R. (1997). The vulnerable observer: Anthropology that breaks your heart. Boston, MA: Beacon.

Ben-David, S., \& Silfen, P. (1992). Staff-to-inmate relations in a total institution: A models of five modes of association. International Journal of Offender Therapy and Comparative Criminology, 36, 209-221.

Cahill, S. E. (1998). Toward a sociology of the person. Sociological Theory, 61, 131-148.

Chambers, E. (2000). Applied ethnography. In N. K. Denzin \& Y. S. Lincoln (Eds.), Handbook of qualitative research (2nd ed., pp. 851-869). Thousand Oaks, CA: SAGE.

Charmaz, K., \& Mitchell, R. G. (1996). The myth of silent author- ship: Self, substance and style in ethnographic writing. Symbolic Interaction, 19, 285-302.

Ciasullo, A. (2008). Containing "deviant" desire: Lesbianism, het- erosexuality and the womenin-prison narrative. Journal of Popular Culture, 41, 195-223.

Clemmer, D. (1940). The prison community. New York, NY: Holt, Rinehart and Winston.

Crawley, E. (2004). Doing prison work: The public and private lives of prison officers. Cullompton, UK: Willan Publishing.

Crewe, B. (2006). Prison drug dealing and the ethnographic lens. The Howard Journal, 45, 347368.

Davies, C. A. (2008). Reflexive ethnography: A guide to research-ing selves and others. Second edition. Abingdon: Routledge.

Denzin, N. K. (1997). Interpretive ethnography: Ethnographic practices for the 21st century. 
Thousand Oaks, CA: SAGE.

Denzin, N. K. and Lincoln, Y. S. (2000). Epilogue. In Denzin, N. K. and Lincoln, Y. S. (eds.) Handbook of Qualitative Research. Second edition. Thousand Oaks: Sage.

Drake, D., \& Harvey, J. (2013). Performing the role of ethnog- rapher: Processing and managing the emotional dimensions of prison research. International Journal of Social Research Methodology. Advance online publication. doi:10.1080/1364 5579.2013.769702

Earle, R. (2013). What do ethnographers do in prison? Reflexivity, trialties and error in prison ethnography. Criminal Justice Matters, 91, 18-19.

Einat, T., \& Chen, G. (2012). "Female inmates" perspectives toward consensual same-sex relationships in an Israeli prison. International Journal of Comparative and Applied Criminal Justice, 36, 25-44.

Emerson, R. M.; Fretz, R. I. and Shaw, L. L. (2001). Participant observation and fieldnotes. In Atkinson, P., Coffey, A., Delamont, S., Lofland, J. and Lofland L. (eds.) Handbook of Ethnography. London: Sage.

Farkas, M. (2000). A typology of correctional officers. International Journal of Offender Therapy and Comparative Criminology, 44, 431-449.

Freedman, E. (1996). Race, class and the construction of the aggressive female homosexual, 1915-1965. Feminist Studies, 22, 397-423.

Giallombardo, R. (1966). Society of women: A study of a women's prison. New York, NY: John Wiley \& Sons.

Goffman, E. (1959). The presentation of self in everyday life. London, England: Penguin.

Goffman, E. (1963). Stigma: Notes on the management of spoiled identity. Harmondsworth, UK: Penguin.

Goffman, E. (1971). Relations in public. New York, NY: Basic Books.

Gold, R. L. (1958). Roles in sociological fieldwork. Social Forces, 36, 217-223.

Greer, K. (2002). Walking an emotional tightrope: Managing emotions in a women's prison. Symbolic Interaction, 25, 117-139.

Hammersley, M., \& Atkinson, P. (2007). Ethnography: Principles in practice. Third edition. London, England: Routledge.

Herman, D. (2003). "Bad girls changed my life": Homonormativity in a women's prison drama. 
Critical Studies in Media Communication, 20, 141-159.

Howe, A. (1994). Punish and critique: Towards a feminist analysis of penalty. London, England: Routledge.

Jewkes, Y. (2012). Autoethnography and emotion as intellectual resources: Doing prison research differently. Qualitative Inquiry, 18, 63-75.

Liebling, A. (1999). Doing research in prison: Breaking the silence? Theoretical Criminology, 3, 147-173.

Liebling, A. (2000). Prison officers, policing and the use of discretion. Theoretical Criminology, 4, 333-357.

Liebling, A. (2001). Whose side are we on? Theory, practice and allegiances in prison research. British Journal of Criminology, 41, 472-484.

Liebling, A., \& Price, D. (2001). The prison officer. Leyhill, UK: Prison Service and Waterside Press.

Lincoln, Y. S. \& Denzin, N. K. (2005). Introduction. In Denzin, N. K. and Lincoln, Y. S. (eds.)

The Sage Handbook of Qualitative Research. Third edition. Thousand Oaks: Sage.

Mathiesen, T. (1965). The defences of the weak. London, England: Tavistock Publications.

Moore, J., \& Jenkins, P. (2012). Coming out' in therapy? Perceived risks and benefits of selfdisclosure of sexual orientation by gay and lesbian therapists to straight clients. Counselling and Psychotherapy Research, 12, 308-315.

Orne, J. (2011). "You will always have to “out" yourself": Reconsidering coming out through strategic outness. Sexualities, 14, 681-703.

Otis, M. (1913). A perversion not commonly noted. Journal of Abnormal Psychology, 8, 113116.

Owen, B. (1998). In the mix: Struggle and survival in a women's prison. Albany: State University of New York Press.

Primeau, L. A. (2003). Reflections on self in qualitative research: stories of family. American Journal of Occupational Therapy. 57, 9-16.

Rhodes, L. (2001). Toward an anthropology of prisons. Annual Review of Anthropology, 30, 6583.

Rhodes, L. (2012, September 18). Ethnographic imagination in the field of the prison. Paper 
presented at the "Resisting the eclipse" symposium, The Open University, Milton Keynes, UK.

Rowe, A. (2009). Negotiating disempowerment: Coping and social support in women's prisons (Unpublished PhD thesis). The Open University, Milton Keynes, UK.

Rowe, A. (2012). Sexuality, criminality and the women's prison: Pat Arrowsmith's 'Somewhere like this." Prison Service Journal, 199, 32-34.

Severance, T. (2008). The prison lesbian revisited. Journal of Gay \& Lesbian Social Services, $17,39-57$.

Spry, T. (2001). Performing autoethnography: An embodied methodological praxis. Qualitative Inquiry, 7, 706-732.

Sykes, G. M. (1958). Society of captives: A study of a maximum security prison. Princeton, NJ: Princeton University Press.

Tait, S. (2011). A typology of prison officer approaches to care. European Journal of Criminology, 8, 440-454.

Van Maanen, J. (Ed.). (1995). Representation in ethnography. Thousand Oaks, CA: SAGE.

Van Maanen, J. (2011 [1988]). Tales of the field: On writing ethnog-raphy. Second edition. Chicago, IL: University of Chicago Press.

Wacquant, L. (2002). The curious eclipse of prison ethnography in the age of mass incarceration. Ethnography, 3, 371-398.

Ward, D. A., \& Kassebaum, G. G. (1965). Women's prison: Sex and social structure. New Brunswick, NJ: Aldine Transaction.

Willet, T. C. (1983). Prison guards in private. Canadian Journal of Criminology, 25, 1-17. 